\title{
UNIVERSITYOF
}

FORWARD

THINKING

WESTMINSTER用

WestminsterResearch

http://www.westminster.ac.uk/westminsterresearch

Heatwave planning: the role of the community in co-producing resilience

Fagan-Watson, B. and Burchell, $\mathrm{K}$.

This is an Accepted Manuscript of an article published by Taylor \& Francis in Building Research and Information, volume 44 (7), pp.754-763, 2016. The final definitive version is available online:

https://dx.doi.org/10.1080/09613218.2016.1209626

The WestminsterResearch online digital archive at the University of Westminster aims to make the research output of the University available to a wider audience. Copyright and Moral Rights remain with the authors and/or copyright owners.

Whilst further distribution of specific materials from within this archive is forbidden, you may freely distribute the URL of WestminsterResearch: ((http://westminsterresearch.wmin.ac.uk/)).

In case of abuse or copyright appearing without permission e-mail repository@westminster.ac.uk 


\title{
Heatwave planning: the role of the community in
}

\section{co-producing resilience}

\author{
Ben Fagan-Watson, \\ Policy Studies Institute at the University of Westminster \\ 35 Marylebone Road \\ London NW1 5LS
}

Tel: 02079117518

Email: b.watson@psi.org.uk

Corresponding author

Kevin Burchell

Policy Studies Institute at the University of Westminster

35 Marylebone Road

London NW1 5LS

Tel: 02079117540

Email: k.burchell@psi.org.uk

ABSTRACT: Drawing on a thematic analysis of relevant policy documents, the aim of this paper is to comment on an apparent disconnect between two associated contemporary UK policy areas: planning for heatwaves and community resilience. Regional and national policy documents that plan for heatwaves in the UK tend to focus on institutional emergency responses and infrastructure development. In these documents, although communities are mentioned, they are understood as passive recipients of resilience that is provided by active institutions. Meanwhile, contemporary discussion about community resilience highlights the potential for involving communities in planning for and responding to emergencies (although the concept is also the subject of critique). Within this context, the paper proposes that - through engagement with the 'community resilience' policy agenda and its critique - effort should be made to articulate and realise greater participation by individuals, and 
voluntary and community sector groups in heatwave preparation, planning and response.

\section{Approach}

The objective of this paper is to comment on two disconnected policy themes that at first glance should be aligned - the notion of 'community resilience' in policy, and planning for extreme hot weather and heatwaves in the UK. The paper explores this issue through an examination of relevant policy documents in the UK. London is used as a case study as it is particularly vulnerable to heatwaves, due to its south east England location and its size, which causes a substantial Urban Heat Island effect - information on London's population and climate can be found in Table 1.

\begin{tabular}{|l|l|}
\hline Population & Over $8.5 \mathrm{~m}^{1}$ \\
\hline $\begin{array}{l}\text { Threshold maximum day and night } \\
\text { temperatures for London, set out in } \\
\text { the Public Health England Heatwave }\end{array}$ & Day: $32{ }^{\circ} \mathrm{C}$ \\
Plan & Night: $18^{\circ} \mathrm{C}$ \\
\hline $\begin{array}{l}\text { Highest temperatures during } 2003 \\
\text { heatwave }\end{array}$ & \\
\hline
\end{tabular}

Academic papers, policy documents and other relevant material were brought together and analysed, drawing on the principles of thematic analysis (e.g.

1 Office for National Statistics (2015) Population Estimates for UK, England and Wales, Scotland and Northern Ireland. Newport, UK: Office for National Statistics.

2 Defined by the Met Office National Severe Weather Warning Service, and cited in Public Health England. (2014b). Heatwave Plan for England: Protecting health and reducing harm from severe heat and heatwaves. [Online] Available: https://www.gov.uk/government/uploads/system/uploads/attachment data/file/31 0598/10087-2902315-TSO-Heatwave Main Plan ACCESSIBLE.pdf [24 April 2015].

${ }^{3}$ Met Office:

http://www.metoffice.gov.uk/climate/uk/interesting/aug03maxtemps.html accessed on 30th June 2016. 
Boyatzis, 1998). In-depth analysis was conducted on key policy documents, selected for their importance to policy on either heatwaves or community resilience; these are detailed in Table 2. There is no heatwave plan for all of London - instead, each local authority has its own documentation. Therefore the Borough of Hounslow was selected to provide one example of a local authority plan for addressing heatwaves.

\begin{tabular}{|l|l|}
\hline $\begin{array}{l}\text { Governance } \\
\text { level }\end{array}$ & Documents \\
governments & $\begin{array}{l}\text { Emergency response } \\
\text { Cabinet Office. (2011a). Guidance: Emergency Preparedness. } \\
\text { Chapter 5: Emergency Planning. } \\
\text { Community resilience } \\
\text { Cabinet Office. (2011b). Strategic National Framework on } \\
\text { Community Resilience. }\end{array}$ \\
$\begin{array}{l}\text { Department of Communities and Local Government (2012) } \\
\text { Regeneration to enable growth: A toolkit supporting community-led } \\
\text { regeneration. }\end{array}$ \\
$\begin{array}{l}\text { Scottish Government. (2013). Building Community } \\
\text { Resilience: Scottish Guidance on Community Resilience. }\end{array}$ \\
$\begin{array}{l}\text { Heatwaves } \\
\text { Defra. (2013). The National Adaptation Programme: Making } \\
\text { the country resilient to a changing climate. }\end{array}$ \\
\hline
\end{tabular}




\begin{tabular}{|c|c|}
\hline & $\begin{array}{l}\text { Public Health England. (2014a). Heatwave Plan for England: } \\
\text { Making the Case: the impact of heat on health - now and in } \\
\text { the future. } \\
\text { Public Health England. (2014b). Heatwave Plan for England: } \\
\text { Protecting health and reducing harm from severe heat and } \\
\text { heatwaves. }\end{array}$ \\
\hline $\begin{array}{l}\text { Regional and } \\
\text { local } \\
\text { government }\end{array}$ & $\begin{array}{l}\text { Greater London Authority. (2011). Managing risks and } \\
\text { increasing resilience: The Mayor's climate change adaptation } \\
\text { strategy. } \\
\text { London Borough of Hounslow (2015) Major Emergency Plan } \\
\text { - Annex: Severe Weather - Heatwave Plan. } \\
\text { London Resilience Partnership (2013) London Resilience } \\
\text { Partnership Strategy v1.0. } \\
\text { London Resilience Partnership (2014) Adverse Weather } \\
\text { Framework. }\end{array}$ \\
\hline
\end{tabular}

\section{The challenge of heatwaves in the UK}

There is a strong evidence base about the risks to health from excess heat that is consistent from around the world (Public Health England, 2014a; 2014b).

Outdoor temperatures above $25^{\circ} \mathrm{C}$ are associated with excess summer deaths in the UK, with higher temperatures associated with a greater numbers of deaths (mortality above what would be expected based on the non-crisis mortality rate in 
the population). During the summer heatwave in Northern Europe in August 2003, unprecedented high day and nighttime temperatures for three days resulted in thousands of excess deaths, initially estimated as 15,000 excess deaths in France (Public Health England, 2014b) and 2,000 in England (Kovats, Johnson and Griffiths, 2006). Subsequent estimates put the figure as high as 70,000 excess deaths across Europe (Robine et al., 2008). The main causes of illness and death during a heatwave are respiratory and cardiovascular diseases, although other causes of death also increase during a heatwave (Gasparrini, Armstrong, Kovats and Wilkinson, 2012).

The Intergovernmental Panel on Climate Change (IPCC) predicts that as a result of climate change, it is very likely that heatwaves will increase in frequency, duration and intensity (IPCC, 2012). The UK Climate Change Risk Assessment (Defra, 2012) notes that there is likely to be an increase in the frequency and severity of extreme weather events (e.g. floods and heatwaves) and states "hot weather accounts for around 1100 premature deaths a year in the UK. By the 2050s, this figure is projected to increase by between 580 and 5900, with the greatest risk in London and southern England." While vulnerability to heat is multi-faceted, the elderly, babies/infants, the ill and disabled, and more deprived social groups are typically the most vulnerable, especially those living alone (Lindley et al., 2011). These groups may be vulnerable to heat not only during a heatwave, but also during persistent hot weather.

Recent work has shown that vulnerable social housing tenants may be especially at risk, particularly those in tower blocks (Mavrogianni, Taylor, Davies, Thoua and Kolm-Murray, 2015). Building and neighbourhood design to counteract excess heat and the Urban Heat Island effect have been widely discussed in academic 
and practitioner literature. Measures to prevent overheating may include situating housing within a certain distance of green spaces and using light-reflecting surfaces and green roofs (Kleerekoper, van Esch and Salcedo, 2012), reducing waste heat produced through energy usage, orientating streets and buildings to provide shade in summer, and using high-albedo (pale and reflective) and permeable paving materials (Greater London Authority, 2011). The UK Climate Change Risk Assessment states that healthcare provision may also be affected by heatwaves if temperatures in hospital wards, care homes and medicine stores are not effectively controlled. Overheating may impact on UK infrastructure in various ways - for example, through higher energy demand for cooling, heat damage/disruption to energy infrastructure, and failure of water supplies (Defra, 2012).

\section{Community resilience}

The concept of resilience is well-established in policy, as well as popular and professional discourse (Hassler and Kohler, 2014). Usage of the word 'resilience' has been traced from Latin into fields such as mechanics and child psychology, before being adopted in the social sciences in the late 1950s (Alexander, 2013). Resilience has also been used in ecology - with reference to a capacity of ecosystems to resist or recover from shocks or stresses - since the 1970s (Norris, Stevens, Pfefferbaum, Wyche and Pfefferbaum, 2008). We do not seek to replicate the substantial amount of work that has been undertaken to define 'resilience', but note that the term is now embraced by planners, urbanists, ecologists, psychologists, engineers, economists and social scientists, and is used in a wide range of contexts, such as cities, infrastructures, IT networks, disasters, climate change and national security, and domains ranging from engineering to ecology to psychology. In these contemporary contexts, resilience 
is typically used to denote one or more elements from this set of capabilities or capacities in the context of adverse conditions or events: to prepare, to respond, to resist, to recover, to learn, to adapt, to thrive and to not change (Miller, et al., 2010; Vale, 2014; Anderies, 2014; Newman, Beatley and Boyer, 2006).

The notion of 'community' is enormously difficult to define, said by researchers to be 'elusive and vague', complex and slippery (Day, 2006: 1), 'contested' (Crow and Mah, 2012: 3) and 'contentious' (Pahl, 2005: 621). We have particularly focused on the 'voluntary and community sector' in this paper, which is distinct from the broader community. Although other understandings are obviously readily available, we use this term to refer to organisations and groups that are not from the 'public sector' (local authorities, emergency services, the NHS and so on) or the 'private sector' (commercial businesses). These can range from national, formally-constituted bodies such as Age UK, to small and highly informal groups for example, parents and staff at a stay-and-play centre. Their work is typically carried out by both volunteers and paid officers (NCVO: https://knowhownonprofit.org/basics/what-is-non-profit).

The term 'community resilience' emerged around the turn of the century (CARRI, 2013) and can be understood to be underpinned by a set of attributes, such as social, economic and human capital, a strong public sector and strong relationships between the public sector and the community (Norris et al., 2008; Miller et al., 2010; CARRI, 2013). It is notable that most definitions of resilience and many of community resilience retain the focus on discrete events, such as: floods, heatwaves, civil disturbances, disease outbreaks, terrorism, etc. However, some definitions suggest resilience is also - or, primarily - relevant in the context of so-called background conditions, such as: economic austerity (Mguni and 
Caistor-Arendar, 2012), oppression (Sonn and Fisher, 1998) and adverse situations (RAND: http://www.rand.org/multi/resilience-in-action.html).

In recent years, the notion of community resilience has entered the UK policy discourse. At the national level, the Cabinet Office defined community resilience as 'Communities and individuals harnessing local resources and expertise to help themselves in an emergency, in a way that complements the response of the emergency services' (Cabinet Office, 2011: 4). Similarly, the Scottish Government defined community resilience as 'Communities and individuals harnessing resources and expertise to help themselves prepare for, respond to and recover from emergencies, in a way that complements the work of the emergency responders' (Scottish Government, 2013: 1). It is notable that these definitions emphasise that communities should complement the work of local institutions, while Twigger-Ross et al. understand community resilience as an ongoing process of communities working with local resources - alongside local expertise - to help themselves and others to prepare for, respond to, and recover from emergencies, which implicitly may or may not include co-operation with local institutions (Twigger-Ross et al., 2015).

\section{Institutional plans for mitigating and responding to heatwaves}

When national and regional policy documents relating to heatwaves in the UK are reviewed, three trends are apparent: they are largely focused on emergency responses rather than long-term preparedness; they almost exclusively focus on actions conducted by public bodies and/or local agencies; and when longer-term planning is mentioned, it focuses on infrastructure development rather than a role for communities. 
Clearly a substantial amount of policy effort has been put into developing emergency responses to heatwaves. The Civil Contingencies Act (2005) requires Category 1 responders (e.g. local authorities, national health bodies) to maintain plans for preventing emergencies; to reduce, control and mitigate the effects of emergencies in both the response and recovery phases; and take other action in the event of emergencies (Cabinet Office, 2011a). Many policy documents use the Heatwave Plan and the Heatwave alert levels developed by Public Health England as a template (Public Health England, 2014b). Local authorities have developed plans with a clear list of actions to take at each level, as a heatwave becomes more likely and as the risk of a severe heatwave rises (London Borough of Hounslow, 2015).

It is notable that institutional plans focus almost exclusively on actions conducted by public bodies and/or local agencies. Almost all of the emergency plans concentrate on clear, step-by-step actions which will allow public bodies to effectively co-ordinate and fulfil their responsibilities to the public. In light of their statutory obligations, local and national policy documents address the roles of public bodies; but the role of other important groups (businesses, civil society etc.) is not further developed. Documents such as the Heatwave Plan for England (Public Health England, 2014b), and the London Resilience Partnership Adverse Weather Framework (London Resilience Partnership, 2014) also almost entirely focus on action by public bodies, and refer to a 'multi-agency' approach of multiple government agencies, rather than multiple societal actors.

When longer-term heatwave resilience planning is detailed, it tends to focus on infrastructure development rather than any kind of community involvement or planning. For example, the Mayor of London's climate change adaptation 
strategy puts forward a number of actions to mitigate heatwaves, which include protecting and extending green space; creating breeze pathways that enhance natural ventilation; orientating streets and buildings to provide shade in summer and passive solar gain in winter; and upgrading the existing housing stock to reduce the risk of overheating (Greater London Authority, 2011). Attempts to build resilience in this way entail top-down judgments about which locations (and which people living in them) are most vulnerable to hazards, and require upfront expense and difficult choices about which parts of the built environment should receive investment (Vale, 2014). Policy on infrastructure, buildings, housing and utilities is complex and overlaps numerous policy domains. Subsequently, it is often not entirely clear in these policy documents who will have responsibility for ensuring that the risk of overheating is addressed.

\section{The role of communities in institutional plans for heatwaves}

Drawing upon case studies of emergencies in the UK, it has been argued that a failure to appreciate the complexities of communities can lead to a waste of local knowledge and expertise, lack of trust in authorities and divisions in communities (Twigger-Ross et al., 2011; Adger et al., 2013). Communities, the voluntary sector and individuals are mentioned in policy documents related to heatwaves, but the roles of these actors in developing and implementing resilience are not clearly explained. The influential Heatwave Plan for England does have a specific list of actions for the 'Community and Voluntary Sector \& Individuals', but seems to envisage communities as an extension of public bodies; the actions recommended for communities mirror those for local authorities (Public Health England, 2014b: 25), including:

- 'Develop a community emergency plan to identify and support vulnerable neighbours in the event of a heatwave' and 'Assess the impact a 
heatwave might have on the provision and use of usual community venues';

- 'Support the provision of good information about health risks especially with those vulnerable groups and individuals';

- 'Keep an eye on people you know to be at risk'; 'stay tuned into the weather forecast and keep stocked with food and medications' and 'check ambient room temperatures'.

Communities (and to a lesser extent businesses) are almost entirely absent from other policy documents relating to heatwaves. One example is the London Resilience Partnership Strategy and delivery plan for 2013-15 (London Resilience Partnership, 2013). One of the few mentions of community is a vague action to 'Promote community resilience initiatives by London resilience partners'. Actions listed in this section are to 'Understand current activities to promote individual and community resilience being carried out by partners' and 'Link with these initiatives to boost recognition of London resilience'. At best, this is mapping of activities and external promotion of the London Resilience Partnership; at worst, it seems like communities have been added as an after-thought.

Recent work has explored the importance of 'middle actors' and intermediaries in systems noting that they are well-positioned to facilitate connections and collaboration between various levels and actors, to introduce and promote innovations, and to structure and support effective and functioning multi-level governance (Parag and Janda, 2014). At the moment this 'middling out' role in heatwave policy seems to be largely left to local policymakers such as London's 32 Boroughs and the City of London rather than actors from community groups or 
other sectors. For example, the heatwave plan for the London Borough of Hounslow defines the local response to a heatwave with step-by-step guidance. It contains few references to community groups, voluntary organisations or the public (London Borough of Hounslow, 2015).

Communities are not only absent from institutional plans; they often have a very weak presence on institutional bodies that respond to heatwaves. A review of the membership of the London Resilience Partnership (London Resilience Partnership, 2013) shows that it is dominated by 'Category one responders' (such as the Emergency services, Greater London Authority, Local Authorities, Health Bodies and Government Agencies) and 'Category two responders' (including utilities, health bodies, transport organizations and the Health and Safety Executive). These are largely public bodies with a statutory duty to plan for emergencies; for example, the London Resilience Partnership Strategy states that "The structures and work programmes established in London provided a strong model for the development of statutory arrangements relating to emergency preparedness in the form of the Civil Contingencies Act which came into effect in 2004" (London Resilience Partnership, 2013: 3). Community groups are only mentioned in a category called 'other responders', where the 'voluntary sector' and 'faith sector' are mentioned. This is mirrored in the make-up of other organizations that deal with extreme weather, or promote resilience.

Voluntary and community groups - which may be formal structured organisations, or can be shifting, informal collaborations that are sometimes temporary in nature - are largely not included in institutional plans for heatwaves. This may partly be explained by the concept of the 'administrative mind', which means that policy makers 'typically pay attention only to problems which are 
amenable to technological and administrative solutions' (Connolly, Smith, Benson, and Saunders, 2012: 155). The structure, mode of operating and heterogeneity of community groups do not fit neatly within the structured flow diagrams of documents like the Public Health England Heatwave Plan. The framing of hot weather and heatwaves as largely either a public health emergency or a technical, long-term planning and infrastructure concern also means that the role of community organisations that are not voluntary emergency responders is less clear. Community groups that work primarily on other issues (for example a local food bank, or cinema club for local pensioners) may struggle to find legitimacy in shaping policy planning and responses - despite the vulnerability to heatwaves of the groups they work with (e.g. people who are socio-economically deprived, elderly, have long-term illnesses etc.).

\section{Why 'the community' should be involved in heatwave planning}

The community is often identified as an entity that has distinctive capabilities because it is 'bottom up' or 'grassroots', in contrast to top-down government action. When they specifically refer to the community or voluntary sector, policy documents view community groups as locally trusted, and able to gain access to vulnerable or 'hard to reach' people (Department of Energy and Climate Change, 2014). They are seen as able to identify and respond to local needs (Department of Communities and Local Government, 2012; HM Government, 2012), mobilise in-depth, local knowledge and ensure more equitable outcomes (Walker and Devine-Wright, 2008). These characteristics lead to a valuable flexibility and nimbleness in the provision of services, and are held to be increasingly valuable in the context of diverse populations (Soteri-Proctor et al., 2010). 
Aiken (2014) has suggested that community action often evokes positive ideas about niches within which social and technological innovation and experimentation can take place. At the same time, community is often associated with a strong and motivating sense of place and identity (Burchell et al., 2014). Community projects in the context of energy, sustainability and food sometimes highlight self-sufficiency (and a resulting empowerment) as a key benefit of community action (Frith et al., 2011; Rezaei and Dowlatabadi, 2015), which has obvious implications for resilience.

There may also be benefits to the process of co-producing a response to heatwaves between voluntary and community sector groups and institutions. Coproduction (also known as 'co-design', 'collaborative design' or 'participatory design') is a collaborative process that brings various stakeholders into the design of policies, plans or services. It has been shown to build trust, tailor and personalise interventions, and empower members of the public and community groups to tackle difficult social and environmental issues (Watson et al., 2013a). Co-production is also characterised by the acknowledgement of, and sometimes requirement for, stakeholders outside of the normal power structures to be involved in problem-solving tasks and crucially in agreeing outcomes (Realpe and Wallace, 2010).

\section{Challenges of community participation and action}

The history of co-design and co-production across numerous domains does suggest there are a number of challenges in involving communities in planning for and responding to heatwaves. The notion of 'community' and 'community engagement' can be problematic - Who is the community? Who should be empowered to speak for the community? These issues are particularly pronounced in London, which is a multicultural city where a wide variety of social 
and cultural identities are evident; the 2010 census showed that $22 \%$ of London residents speak another language (not English) as their 'main language' (Office for National Statistics, 2013) In the field of emergency response in the UK, the term 'community' has been considered by policymakers in emergency response as self-evident and unproblematic, and synonymous with 'the public' (TwiggerRoss et al., 2011). However society can be viewed as multiple communities or groups and ever-shifting power relations, thus raising the potential for division, exclusion, conflict and oppression.

These challenges are highlighted in discussions of community energy projects in which organisers, supporters and opponents of projects find themselves in conflict (Cass, Walker and Devine-Wright, 2010; Walker et al., 2010; Walker, 2011). It follows that participatory processes at the community scale will also be characterised by power relations and division; only some will be able to speak, only some things can be said, and only some things will happen. As a result, critics argue that public participation approaches are prone to capture by particular - often middle class or elite - groups (Cooke and Kothari, 2001). More broadly, Innes and Boohar (2004) argue that public participation processes in the US are often antagonising and discouraging for participants - who feel not heard, and pitted against each other. The process can also be discouraging for public officials, who feel unable to take public views on board.

There are also ethical, moral and political dimensions to the decision to involve communities in planning for and responding to heatwaves. Examining policies to mitigate flooding in the UK, Lewis and Kelman state that 'it is difficult not to conclude that policies for community resilience in places of identifiable vulnerability obscure more challenging, underlying political issues. Community 
resilience papers over the cracks of vulnerability without solving the deep challenges' (Lewis and Kelman, 2010: p206). Various authors have noted that increasing the role of communities in policymaking can be a way of making policymaking more contextually appropriate, nuanced, flexible or effective; but equally it can place the burden of public services onto the voluntary sector, while the state retreats from areas it previously had responsibility to cover. For example, Petcou and Petrescou (2015: p256) have cautioned that embracing a program of economic resilience in which the state is absent would "explicitly promote the reliance on unpaid work to mask the disappearance of welfare structures and the massive cuts in public services." The trend of central government encouraging community ownership of issues has been characterised as a hybrid between ascendant neoliberalism (with devolution, deregulation and central government spending cuts) and contemporaneous trends in the management of environmental and social issues (McCarthy, 2005). In the context of government cuts there are difficult questions to ask about the extent to which communities should self-organise to protect their most vulnerable members; and the extent to which they may be filling in for decreasing national and local government expenditure.

The involvement of 'vulnerable' people in planning responses to heatwaves may be difficult, as past research suggests many people who are vulnerable to the effects of extreme heat do not see messages about heatwaves as relevant to them. Research with older people in London and Norwich (Abrahamson et al., 2009) found that intended target groups for messages about heatwaves may not be receptive to messages from public bodies; few of the respondents that Abrahamson and colleagues interviewed (aged 72-94 years) considered themselves either old or at risk from the effects of heat, even though many had 
some form of relevant chronic illness, and 'do not think of themselves as the intended recipients of heatwave warnings'. Secondly, Abrahamson et al. found that the 'vulnerable' people that heatwave plans are meant to target may not see state-led intervention as desirable or useful. Some respondents fully endorsed the role of the state in protecting the population at risk, but others believed that state intervention was 'uncalled for, intrusive, patronizing and infringed upon or threatened individuals independence, or was an inappropriate use of resources'.

\section{Interventions that will improve preparation for and responses to heatwaves}

While bearing in mind the challenges outlined above, the authors believe that engaging with 'the community' in some form will improve policymaking on heatwaves in the UK due to the numerous benefits listed above. This paper proposes that voluntary and community groups could play a role in governance, policy, planning and response to heatwaves. A number of interventions could be undertaken in the UK:

1. Map, and network with, community groups: policymakers have sometimes reached out to community groups more successfully in planning for flooding than they have in planning for heatwaves. For example, Kent Resilience Forum has a 'Kent Voluntary Sector Group' which co-ordinates 20 local voluntary groups (e.g. the Kent $4 \times 4$ owners club) in the event of an emergency (http://www.kentcan.org/our-activities/providing-sectorperspective/ - accessed on $11^{\text {th }}$ May 2016). This seems like an opportunity to transfer learning from the domain of flooding to heatwaves. Local authorities co-ordinate responses to heatwaves in their area, and they should attempt to identify and reach out to community groups in their locality. The aim of this outreach would be to work with community groups to reach vulnerable and 'hard to reach' people that local institutions may 
not have access to, with the offer of assistance or information in the event of a heatwave.

2. Establish formal, ongoing relationships: it is apparent from the review of policy documents that community groups are often excluded from institutional structures (London Resilience Partnership, 2013 and London Borough of Hounslow, 2015). To facilitate an ongoing relationship, the local authorities should involve some representatives of voluntary and community organisations in their formal structures - for example, the inclusion of community groups on the Borough Resilience Forum, which co-ordinates local agencies in preparing for emergencies.

3. Co-produce plans for heatwaves, particularly longer-term plans: there are numerous benefits to involving community stakeholders in planning for emergencies including democratic legitimacy, accountability and enhanced governance, and more efficient and better services (e.g. INVOLVE, 2005). Local authorities and other key public bodies (hospitals, emergency services, housing associations etc.) should try to involve community groups (particularly those that work with people vulnerable to extreme hot and cold weather) in the longer-term planning required to make an area resilient to heatwaves; for example, in discussions about housing, town planning and redevelopment. In particular, local institutions should undertake co-production of planning for, and policy and response to, heatwaves. This would involve meaningful two-way discussions with community groups about their plans in the event of a heatwave, ensuring they have the flexibility to adjust their plans. Various research projects in the UK have found that community stakeholders can bring rich, detailed 
knowledge of their area, communities, local resources and networks to complement policy processes (Watson, Bowden, McGeevor, Brass, and Mitrovic, 2013b; Burchell, Rettie and Roberts, 2014; Boyle and Harris, 2009).

4. Finally, work in this area will need to be properly resourced in order to be effective, and it is suggested that policymakers from both national (Cabinet Office, Defra, Public Health England etc.) and regional bodies (e.g. the Greater London Authority) explore ways to support community groups in responding to heatwaves. Analysis of the position of the voluntary and community sector in the UK in 2015 found that it was in a 'fragile position', with government grants at an all-time low, and the sector experiencing a 'capacity crunch' (NCVO, 2015) which will limit the ability of voluntary and community groups to engage with new policy agendas. This could be through direct funding (although the groups chosen to represent 'the community' will need to be chosen with care, and through engagement with local stakeholders) or through support for organisations that support community groups in their local area.

\section{Conclusion}

The review of policy documents and processes relating to heatwaves in the UK shows that voluntary and community groups play a limited role in emergency response, but have no role in the broader planning for and response to heatwaves. This is a striking characteristic, given that there is so much emphasis on community resilience in other areas of policy. The Mayor of London's climate change adaptation strategy states that "No single authority is individually responsible, or capable, of increasing our resilience to climate risks. To 
effectively sustain and even increase our resilience, we need the climate to be routinely considered in all significant decisions and more joint working across the public, private and voluntary sectors" (Greater London Authority, 2011). Policymakers will need to make significant changes to their plans and community engagement strategies for dealing with heatwaves if they are to enact the multilevel governance and complex social picture this statement encapsulates.

The literature has shown that there are numerous benefits to engaging the community and voluntary sector in preparing for and responding to heatwaves, as well as practical and ethical challenges about engaging with 'the community' in practice. Engaging with 'the community' to foster greater community resilience will not necessarily be easy; while policymakers working in civil contingencies and emergency planning have often viewed the idea of community as self-evident and unproblematic, this paper has highlighted evidence that 'community' is much more complex, and may involve multiple competing groups with potentially conflicting interests, as many previous studies have pointed out. Despite the challenges detailed above, there does seem to be considerable potential for improving the effectiveness of preparation for and responses to heatwaves in the UK through increasing the role of community groups. This paper proposes interventions for articulating and realising community-led responses to heatwaves, noting the varied evidence on the limitations of institutional responses, and calls for institutions to include communities in their preparation, planning for and response to emergencies.

Heatwaves have been on the governments' agenda in the UK since the excess summer deaths in Northern Europe in 2003, but it remains a relatively new and under-developed policy area. At both the national and local level, government 
bodies in the UK have focused on narrowly defined, public sector responses to heatwave emergencies. They have simultaneously marginalised the role of community groups and 'the public', and largely failed to address the longer-term issues (neighbourhood design, largescale retrofit, etc.) required to effectively deal with heatwaves in the UK. In conclusion, there is a significant opportunity to involve communities in the design and implementation of heatwave policy and planning.

\section{Acknowledgements}

This work was supported by the Joseph Rowntree Foundation through the 'Urban Heat' project grant. This paper was presented at the Architecture and Resilience Research Conference at the University of Sheffield in September 2015. We are grateful for the helpful comments we received from the editor of this journal, the conference organisers, the attendees, the editor of this special issue and all reviewers.

\section{References}

Abrahamson, V., Wolf, J., Lorenzoni, I., Fenn, B., Kovats, S., Wilkinson, P.,... Raine, R. (2009). Perceptions of heatwave risks to health: interview-based study of older people in London and Norwich, UK, Journal of Public Health, 31(1): 119-126.

Adger, N., Barnett, J., Brown, K., Marshall, N., O’Brien, K. (2012). Cultural dimensions of climate change impacts and adaptation. Nature Climate Change, 3, 112-117.

Aiken, G. (2014). (Local-) community for global challenges: carbon conversations, transition towns and governmental elisions. Local Environment 20(7), 764-781.

Alexander, D. (2013). Resilience and disaster risk reduction: an etymological journey. Natural Hazards and Earth System Sciences, 13, 2707-2716 
Anderies, J. (2014). Embedding built environments in Social-ecological systems: resilience-based design principles. Building Research and Information, 42(2), 130-142.

Arnstein, S. (1969). A ladder of participation. JAIP, 35(4), 216-224.

Bosher, L. (2014). Built-in resilience through disaster risk reduction: operational issues. Building Research and Information, 42(2), 240-254.

Boyatzis, R.E. (1998). Transforming qualitative information: Thematic analysis and code development. Thousand Oaks, London, \& New Delhi: SAGE Publications.

Boyle D. \& Harris ,M. (2009). The challenge of co-production: How equal partnerships between professionals and the public are crucial to improving public services. London: Nesta.

Burchell, K., Rettie, R. \& Roberts, T. (2014). Smart Communities: working together to save energy? Behaviour and Practice Research Group, Kingston University. Available: $\underline{\text { http://business.kingston.ac.uk/smart-communities }}$

Cabinet Office. (2011a). Guidance: Emergency Preparedness. Chapter 5: Emergency Planning [Online] Available:

https://www.gov.uk/government/uploads/system/uploads/attachment data/file/61028/Emergency P reparedness chapter5 amends 21112011.pdf [24 April 2015].

Cabinet Office. (2011b). Strategic National Framework on Community Resilience HMG London [Online] Available: http://www.cabinetoffice.gov.uk/resource-library/community-resilience-resourcesand-tools [24 April 2015].

CARRI. (2013). Definitions of community resilience: An analysis. Washington DC: Meridian Institute. 
Cass, N., Walker, G. \& Devine-Wright, P. (2010). Good Neighbours, Public Relations and Bribes: The Politics and Perceptions of Community Benefit Provision in Renewable Energy Development in the UK. Journal of Environmental Policy \& Planning, 12(3), 255-275.

Connolly, J., Smith, G., Benson, D., \& Saunders, C. (2012). Politics and the Environment: From Theory to Practice - Third Edition. Abingdon: Routledge.

Cooke, B. \& Kothari, U. (2001). Participation: the new Tyranny . New York: Palgrave.

Crow, G., \& Mah, A. (2012). Conceptualisations and meanings of "community": the theory and operationalisation of a contested concept. [Online] Available http://www.ahrc.ac.uk/documents/project-reports-and-reviews/connectedcommunities/conceptualisations-and-meanings-of-community-the-theory-and-operationalization-ofa-contested-concept/ [11 May 2016]

Day, G. (2006). Community and Everyday Life. Routledge: Abingdon

Department of Communities and Local Government. (2012). Regeneration to enable growth: A toolkit supporting community-led regeneration. Department of Communities and Local Government: London.

Department of Energy and Climate Change. (2014). Community Energy Strategy. DECC, London. [Online] Available: https://www.gov.uk/government/publications/community-energy-strategy [24 April 2015].

Defra. (2012). UK Climate Change Risk Assessment: Government Report. [Online] Available: https://www.gov.uk/government/uploads/system/uploads/attachment data/file/69487/pb13698climate-risk-assessment.pdf [24 April 2015].

Defra. (2013). The National Adaptation Programme: Making the country resilient to a changing climate. [Online] Available: https://www.gov.uk/government/publications/adapting-to-climatechange-national-adaptation-programme [24 April 2015]. 
Firth, C. Maye, D. \& Pearson, D. (2011). Developing "community" in community gardens. Local Environment 16(6), 555-568

Gasparrini, A., Armstrong, B., Kovats, S. \& Wilkinson, P. (2012). The effect of high temperatures on cause-specific mortality in England and Wales. Occupational and environmental medicine. 69(1), $56-61$.

Greater London Authority. (2011). Managing risks and increasing resilience: The Mayor's climate change adaptation strategy [Online] Available:

https://www.london.gov.uk/sites/default/files/Adaptation-oct11.pdf [24 April 2015].

Hassler, U \& Kohler, N (2014). Resilience in the built environment. Building Research and Information, 42(2), 119-129.

HM Government. (2012a). Open Public Services White Paper (Cm 8145). Norwich: HM Stationary Office.

Innes, J. \& Booher, D. (2004). Reframing public participation: strategies for the 21 st century. Planning Theory \& Practice, 5(4), 419-436.

Intergovernmental Panel on Climate Change. (2012). Managing the risks of extreme events and disasters to advance climate change adaptation: Summary for Policymakers. [Online] Available: http://ipcc-wg2.gov/SREX/images/uploads/SREX-SPMbrochure FINAL.pdf [24 April 2015].

INVOLVE. (2005). People and participation: how to put citizens at the heart of decision-making [Online] Available: http://www.involve.org.uk/blog/2005/12/12/people-and-participation/ [24 April 2015].

Kleerekoper L, van Esch, M \&Salcedo, T.B. How to make a city climate-proof, addressing the urban heat island effect. Resources, Conservation and Recycling, 64, 30-8. 
Kovats, R., Johnson, H. \& Griffiths, C. (2006). Mortality in southern England during the 2003 heat wave by place of death. Health Statistics Quarterly, 29, Spring 2006.

Lewis, J. \& Kelman, I. (2010). Places, people and perpetuity: Community capacities in ecologies of catastrophe. ACME: An International E-Journal for Critical Geographies, 9 (2), 191-220.

Lindley, S., O’Neill, J., Kandeh, J., Lawson, N., Christian, R. \& O’Neill, M. (2011). Climate change, justice and vulnerability. [Online] Available: http://www.jrf.org.uk/sites/files/jrf/climate-change-justicevulnerabilityEBOOK.pdf [24 April 2015].

London Borough of Hounslow. (2015). Major Emergency Plan - Annex: Severe WeatherHeatwave Plan. Unpublished work.

London Resilience Partnership. (2013). London Resilience Partnership Strategy v1.0. [Online] Available:

https://www.Iondon.gov.uk/sites/default/files/London\%20Resilience\%20Partnership\%20Strategy\%2 Ov1\%20web\%20version 1.pdf [24 April 2015].

London Resilience Partnership .(2014). Adverse Weather Framework [Online] Available: https://www.london.gov.uk/sites/default/files/AdverseWeatherFramework\%201.0\%20web.pdf [24 April 2015].

Maguire, B. \& Cartwright S. (2008). Assessing a community's capacity to manage change: $A$ resilience approach to social assessment. Canberra: Australian Government Bureau of Rural Sciences.

Mavrogianni, A., Taylor, J., Davies, M., Thoua, C. \& Kolm-Murray, J. (2015). Urban social housing resilience to excess summer heat. Building Research and Information, 43(3), 316-333.

McCarthy, J. (2005) Devolution in the woods: community forestry as hybrid neoliberalism. Environment and Planning A ,, 37, 995-1014. 
Mguni, N. \& Caistor-Arenda, L. (2012) Rowing against the tide: making the case for community resilience. London: Young Foundation.

Miller, F., Osbahr, H., Boyd, E., Thomalla, F., Bharwani, S., Ziervogel, G., Nelson, D. (2010). Resilience and Vulnerability: Complementary or Conflicting Concepts? Ecology and Society, 15(3), p.11. [online] URL: http://www.ecologyandsociety.org/vol15/iss3/art11/

NCVO (2015) A financial sustainability review of the voluntary sector. London: NCVO. Available at https://www.ncvo.org.uk/images/documents/policy and research/funding/financial-sustainabilityreview-of-the-voluntary-sector-july-2015.pdf [Accessed on 30th June 2016].

Newman, P., Beatley, T., \& Boyer, H. (Eds.). (2006). Resilient cities: Responding to peak oil and climate change. Washington, DC: Island Press.

Office for National Statistics. (2015). Population Estimates for UK, England and Wales, Scotland and Northern Ireland. Newport, UK: Office for National Statistics.

Office for National Statistics. (2013). Statistical bulletin: 2011 Census: Quick Statistics for England and Wales, March 2011. Newport, UK: Office for National Statistics.

Norris, F. Stevens, S., Pfefferbaum, B., Wyche, K.\& Pfefferbaum, R. (2008). Community Resilience as a Metaphor, Theory, Set of Capacities, and Strategy for Disaster Readiness. American Journal of Community Psychology. 41:127-150.

Pahl, R. (2005). Are all communities communities in the mind? The Sociological Review, 53 (4), 621640.

Parag, Y. \& Janda, K. (2014). More than filler: Middle actors and socio-technical change in the energy system from the "middle-out". Energy Research \& Social Science, 3, 102-112.

Petcou C. \& Petrescu D. (2015). R-Urban or how to co-produce a resilient city Ephemera: theory and politics in organisation, 15(1). Available at: 

Jan 2016].

Public Health England. (2014a). Heatwave Plan for England: Making the Case: the impact of heat on health - now and in the future. [Online] Available:

https:/www.gov.uk/government/uploads/system/uploads/attachment data/file/310604/100882902328-TSO-Heatwave-Making the Case ACCESSIBLE.pdf [24 April 2015].

Public Health England. (2014b). Heatwave Plan for England: Protecting health and reducing harm from severe heat and heatwaves. [Online] Available:

https:/www.gov.uk/government/uploads/system/uploads/attachment data/file/310598/100872902315-TSO-Heatwave Main Plan ACCESSIBLE.pdf [24 April 2015].

Realpe, A. \& Wallace, L. (2010) What is co-production? London: Health Foundation. [Online] Available: http://personcentredcare.health.org.uk/sites/default/files/resources/what is coproduction.pdf

Rezaei, M. \& Dowlatabadi, H. (2015). Off-grid: community energy and the pursuit of self-sufficiency in British Columbia's remote and First Nations communities. Local Environment. [Online] Available http://www.tandfonline.com/doi/pdf/10.1080/13549839.2015.1031730 [11 May 2016]

Robine, J-M., Cheung, Siu Lan K., Le Roy, S., Van Oyen, H., Griffiths, C., Michel, J-P \& Herrmann, F. R. (2008). Death toll exceeded 70,000 in Europe during the summer of 2003. Comptes Rendus Biologies, 331 (2), p171-178. Available:

http://www.sciencedirect.com/science/article/pii/S1631069107003770 [24 April 2015].

Scottish Government. (2013). Building Community Resilience: Scottish Guidance on Community Resilience. Edinburgh: Safer Scotland. Available:

http://www.gov.scot/Resource/0042/00421210.pdf

Sonn, C., \& Fisher, A. (1998). Sense of community: community resilient responses to oppression and change. Journal of Community Psychology, 26(5), 457-472. 
Soteri-Proctor, A., Phillimore, J. \& McCabe, A. (2013). Grassroots civil society at crossroads: staying on the path to independence or turning onto the UK Government's route to localism? Development in Practice, 23(8), 1022-1033

Twigger-Ross, C., Coates, T., Deeming, H., Orr, P., Ramsden M. \& Stafford, J. (2011). Community Resilience Research: Final Report on Theoretical research and analysis of Case Studies report to the Cabinet Office and Defence Science and Technology Laboratory. London: Collingwood Environmental Planning Ltd.

http://static1.squarespace.com/static/54c22ee7e4b060a897523254/t/5639054be4b09d39bcec4da4/ 1446577483128/CEP+DSTL+Community+Resilience_FINAL+REPORT.pdf [25 January 2016].

Twigger-Ross, C., Brooks, K., Papadopoulou, L., Orr, P., Sadauskis, R., Coke, ... Walker, G. (2015). Community Resilience to Climate Change: an evidence review. York: Joseph Rowntree Foundation.

Vale, L. (2014). Built-in resilience through disaster risk reduction: operational issues. Building Research and Information, 42(2), 191-201.

Walker, G. (2011). The role for 'community' in carbon governance. Wiley Interdisciplinary Reviews: Climate Change, 2, 777-782.

Walker, G., Devine-Wright, P., Hunter, S., High, H.\& Evans, B. (2010). Trust and community: Exploring the meanings, contexts and dynamics of community renewable energy. Energy Policy, 38, 2655-2663.

Walker, G. \& Devine-Wright, P. (2008). Community renewable energy: What should it mean? Energy Policy, 36, 497-500.

Watson, B., Bowden, F., McGeevor, K., Brass, C., \& Mitrovic, D., (2013a) Community Co-design: A guide to working collaboratively through design. London: Defra. 
Watson, B., Bowden, F., McGeevor, K., Brass, C., \& Mitrovic, D., (2013b). Food Loop: a technical research report for the Department for Environment, Food and Rural Affairs. Technical Report. London: Defra.

Whittle, R., Medd, W., Deeming, H., Kashefi, E., Mort, M., Twigger Ross, C., ... Watson, N. (2010). After the Rain - learning the lessons from flood recovery in Hull, final project report for "Flood, Vulnerability and Urban Resilience: a real-time study of local recovery following the floods of June 2007 in Hull $\square$, Lancaster: Lancaster University. 